\title{
Multivariate statistical evaluation of dissolved heavy metals and a water quality assessment in the Lake Aha watershed, Southwest China
}

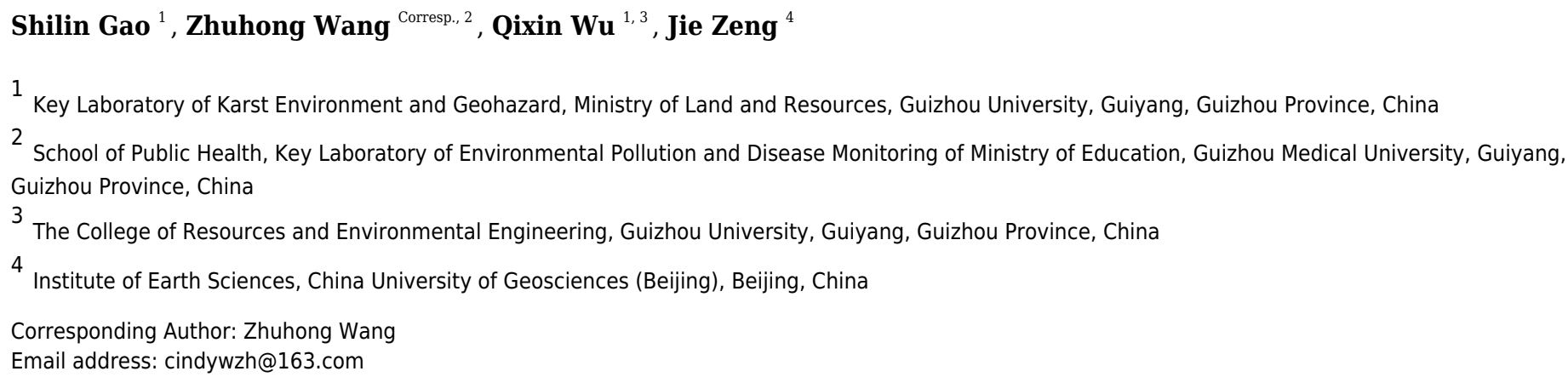

Heavy metals are of public concern in aquatic ecosystems due to their growing release from industries and mining activities. This study investigated the sources, temporal-spatial distributions and water quality of dissolved heavy metals ( $\mathrm{Mn}, \mathrm{Co}, \mathrm{Al}, \mathrm{Ni}, \mathrm{Ba}, \mathrm{V}, \mathrm{Sb}, \mathrm{Fe}, \mathrm{Sr}$ ) in the Lake Aha watershed, an area under the influence of sewage and acid mining drainage. These heavy metals displayed significant spatial and temporal variabilities. The water quality index results (WQI values ranged from 3.21 to 15.64 ) and health risk assessment (all hazard indexes are below 1 ) indicated that dissolved heavy metals in this study pose a low risk for human health. Correlation analysis and principal component analysis indicated that Fe and Sr mainly presented a natural geological feature in the study area, and $\mathrm{Mn}, \mathrm{Co}, \mathrm{Al}$ and Ni were influenced by the acid coal mine drainage, whereas $\mathrm{Ba}, \mathrm{V}$ and $\mathrm{Sb}$ were under the impact of local industrial or medical activities. This study provides new insights into the risk assessment of heavy metals in small watersheds. 
1 Multivariate statistical evaluation of dissolved heavy metals

2 and a water quality assessment in the Lake Aha watershed,

3 Southwest China

4

5

6

7

8

Shilin $\mathrm{Gao}^{1}$, Zhuhong Wang ${ }^{2}$, Qixin $\mathrm{Wu}^{1,3}$, Jie Zeng ${ }^{4}$

${ }^{1}$ Key Laboratory of Karst Environment and Geohazard, Ministry of Land and Resources, Guizhou University, Guiyang, China

${ }^{2}$ School of Public Health, Key Laboratory of Environmental Pollution and Disease Monitoring of Ministry of Education, Guizhou Medical University, Guiyang, China

${ }^{3}$ The College of Resources and Environmental Engineering, Guizhou University, Guiyang, China

${ }^{4}$ Institute of Earth Sciences, China University of Geosciences (Beijing), Beijing, China

Corresponding Author:

Zhuhong Wang ${ }^{2}$

Guiyang, Guizhou Province, 550000, China

Email address: cindywzh@163.com

\section{Abstract}

Heavy metals are of public concern in aquatic ecosystems due to their growing release from industries and mining activities. This study investigated the sources, temporal-spatial distributions and water quality of dissolved heavy metals ( $\mathrm{Mn}, \mathrm{Co}, \mathrm{Al}, \mathrm{Ni}, \mathrm{Ba}, \mathrm{V}, \mathrm{Sb}, \mathrm{Fe}, \mathrm{Sr}$ ) in the Lake Aha watershed, an area under the influence of sewage and acid mining drainage. These heavy metals displayed significant spatial and temporal variabilities. The water quality index results (WQI values ranged from 3.21 to 15.64) and health risk assessment (all hazard indexes are below 1) indicated that dissolved heavy metals in this study pose a low risk for human health. Correlation analysis and principal component analysis indicated that Fe and $\mathrm{Sr}$ mainly presented a natural geological feature in the study area, and $\mathrm{Mn}, \mathrm{Co}, \mathrm{Al}$ and $\mathrm{Ni}$ were influenced by the acid coal mine drainage, whereas $\mathrm{Ba}, \mathrm{V}$ and $\mathrm{Sb}$ were under the impact of local industrial or medical activities. This study provides new insights into the risk assessment of heavy metals in small watersheds.

\section{Introduction}

With the growth of industrial, mining and economic activities, surface water quality is facing enormous challenges (Islam et al. 2015; Ustaoğlu et al. 2020a; Vörösmarty et al. 2010). Among challenges, heavy metal contamination is of particular concern (Ariffin et al. 2017; Burakov et al. 2018; Cameron et al. 2018; Islam et al. 2015). Dissolved heavy metals in water could readily 
enter the food chain, which eventually leads to serious health risks to ecosystems and humans (Nguyen et al. 2018; Rehman et al. 2018). Heavy metals in water are primarily released from natural processes and anthropogenic activities (Li \& Zhang 2010; Meng et al. 2016). Natural processes include atmospheric dry/wet deposition, rock weathering, and volcanism, which are related to the local geology and lithology characteristics (Han \& Liu 2004; Krishna et al. 2009; Li \& Zhang 2010; Nriagu 1989). Anthropogenic activities including industrial, mining, medical, and urban sewage can release a large number of heavy metals into the aquatic systems (Han et al. 2019; Meng et al. 2016; Pekey et al. 2004).

To understand the health risks of heavy metals in waters, it is crucial to investigate the concentration, distribution, and sources of heavy metals. According to the concentration, distribution, of heavy metals in aquatic systems, the sources of heavy metals from natural processes or human activities can be qualitatively identified via multivariate statistical approaches, such as correlation analysis and principal component analysis (PCA) (Xiao et al. 2019; Zeng et al. 2019a). Ingestion and dermal absorption are two main exposure pathways for aqueous heavy metals. To estimate the potential non-carcinogenic risks, the hazard quotient (HQ) has been commonly used in previous studies (Ustaoğlu et al. 2020c; Wu et al. 2009; Xiao et al. 2019), which is the ratio between exposure or average intake of contaminants and the corresponding reference dose (RfD). The water quality index (WQI) has been used to reflect the comprehensive influence of various dissolved heavy metals in water (Meng et al. 2016; Taş et al. 2019; Ustaoğlu et al. 2020b; Xiao et al. 2019).

Lake Aha is a primary reservoir of tap water for Guiyang, the capital of Guizhou Province, SW China. With rapid economic development in the last decades, the ecological environment of the Lake Aha watershed is strongly impacted by urban and industrial activities. Several studies reported heavy metal contamination in the Lake Aha watershed, however, these studies mainly concerned heavy metals in solid phases such as suspended particulate matter and sediments (Huang et al. 2009; Song et al. 2011; Zhang et al. 2019). It becomes increasingly important to investigate the contamination, source, and health risk of dissolved heavy metals in the Lake Aha watershed.

In this study, to facilitate drinking water management efficiency and provide a reference for the policy formulation of heavy metal pollution prevention, we systematically investigated nine heavy metals in three inflowing tributaries of Lake Aha. The aims are to (1) investigate the temporal-spatial distribution patterns of dissolved heavy metals in the tributaries; (2) identify the potential sources of heavy metals, and (3) assess the water quality and the ecological risk of dissolved heavy metals.

\section{Materials \& Methods} Study Site 
80 The Lake Aha watershed is located in Guiyang City, Southwest China $\left(26^{\circ} 34^{\prime} \mathrm{N} ; 1^{\circ} 6^{\circ} 43^{\prime} \mathrm{E}\right)$, 81 which holds a total area of $180.2 \mathrm{~km}^{2}$ with a population of almost 150000 and provides the vital 82 water source for the local city (Han et al. 2010). The watershed is situated on the Yunnan-

83 Kweichow Plateau, the global largest karst region, where karst aquifers and conduit networks are 84 especially vulnerable to anthropogenic contaminations (Sun et al. 2019). The study site has a 85 subtropical humid and monsoon climate, with a mean annual temperature of about $23.2^{\circ} \mathrm{C}$. The 86 average annual rainfall ranges from 1140 to $1200 \mathrm{~mm}$, while the average annual evaporation is $87932 \mathrm{~mm}$ (Bai et al. 2007; Pan et al. 2019). The average annual rainfall days are about 178 days and most of the precipitation is mainly from May to August, accounting for about $65 \%$ of the total, with a relatively short annual average sunshine time over 1412.6 hours.

Lake Aha has three major inflowing tributaries, namely the Youyu River (YR), the Baiyan River (BR), and the Jinzhong River (JR). The bedrock of the Youyu River is Permian limestone and Triassic shale, while that of the Baiyan River is Triassic dolomite and shale, and that of Jinzhong River is Triassic dolomite (Song et al. 2011). The Youyu River covers an area of $61.9 \mathrm{~km}^{2}$ and flows eastward for $18.5 \mathrm{~km}$ through 11 villages. Agricultural land (53.0\%) is the primary land use type of the Youyu River watershed, whereas residential and commercial land is small (3.3\%). The Baiyan River drains $51.5 \mathrm{~km}^{2}$ and is approximately $15 \mathrm{~km}$ long. The primary land use type of the Baiyan River watershed is forest (40.2\%). The Jinzhong River has a length of $16.5 \mathrm{~km}$ and a watershed area of $47.5 \mathrm{~km}^{2}$ with around 60,000 inhabitants. The dominant land use type of the Jinzhong River watershed is residential and commercial land (81.6\%), indicating the Jinzhong River is intensively affected by human activities.

\section{Sampling and analysis}

River water samples were collected from $10 \mathrm{~cm}$ below the surface water level, at 18 sites in the tributaries, once a month from November 2017 to April 2018 (low flow season). The sampling sites are shown in Figure 1. Specifically, 9 sites were located in the Youyu River, 6 sites were located in the Baiyan River, and 3 sites were located in the Jinzhong River.

Ultimately, a total of 103 river water samples were collected, however, 5 of them were damaged during transportation. The $\mathrm{pH}$, electrical conductivity (EC) and dissolved oxygen (DO) values of water samples were immediately measured in the field using the WTW Multi3430 (WTW Company, Weilheim, Upper Bavaria, Germany). The samples were instantly filtered through $0.22 \mu \mathrm{m}$ acetate cellulose-acetate membrane after collection. All the water samples were acidified with ultra-purified $\mathrm{HNO}_{3}(\mathrm{pH}<2)$, then sealed in pre-cleaned polyethylene bottles and kept at $4^{\circ} \mathrm{C}$ until determination.

\section{Heavy metals analysis}

Nine heavy metals (Mn, Co, Al, Ni, Ba, V, Sb, Fe, and Sr) were detected by using ICP-MS (NexION300X; Perkin Elmer, Waltham, MA, USA) at the Institute of Geochemistry, Chinese 
120 Academy of Sciences. Quality assurance and quality control were assessed by standard operating 121 procedures, calibration with standards, and analysis of reagent blanks, with each batch of 20

122

123

124

125

126

127

128

129

130

131

132

133

134

135

136

137

138

139

140

141

142

143

144

water samples. Relative standard deviations (RSD) for heavy metals were $\pm 5 \%$ and recovery percentage ranged from $90 \%$ to $110 \%$. Otherwise, the samples were detected again until the data reach the standard.

\section{Statistical analysis}

Multivariate statistical approaches, including correlation analysis and principal component analysis (PCA), were used to identify the possible origin of nine heavy metals in the study area (Ustaoğlu \& Tepe 2019; Xiao et al. 2019). PCA is the most common approach to explore the sources of heavy metals by reducing the dimensionality of the dataset to several influencing factors (Loska \& Wiechuła 2003; Zeng et al. 2019b). The suitability of the datasets for the PCA method is assessed by Kaiser-Meyer-Olkin (KMO) value and Bartlett's sphericity test ( $\mathrm{p}<$ 0.001) (Varol 2011). Microsoft Office 2019 and the statistical software package SPSS 21.0 were used to perform all of the data processing.

\section{Health risk assessment}

The hazard index (HI), the sum of both two pathway HQs, represents total potential noncarcinogenic risks for each heavy metal. If HQ or HI exceeds 1, it indicates a potentially adverse effect on human health and needs for further study (Wang et al. 2017). The HQ and HI are calculated as follows:

$$
\begin{gathered}
A D D_{\text {ingestion }}=\left(C_{w} \times I R \times E F \times E D\right) /(B W \times A T) \quad(1) \\
A D D_{\text {dermal }}=\left(C_{w} \times S A \times K_{p} \times E T \times E F \times E D \times 10^{-3}\right) /(B W \times A T) \\
H Q=A D D / R f D \quad(3) \\
R f D_{\text {dermal }}=R f D \times A B S_{G I} \\
H I=\sum H Q s \quad \text { (5) }
\end{gathered}
$$

where $\mathrm{ADD}_{\text {ingestion }}$ and $\mathrm{ADD}_{\text {dermal }}$ are the average daily doses via ingestion or dermal exposure $\left(\mu \mathrm{g} / \mathrm{kg} /\right.$ day), respectively. $\mathrm{C}_{\mathrm{w}}$ is the heavy metal concentration of each sample $(\mu \mathrm{g} / \mathrm{L})$; IR is the ingestion rate (L/day); $\mathrm{EF}$ is the exposure frequency (day/year); $\mathrm{ED}$ is the exposure duration (years); BW is the body weight $(\mathrm{kg})$; AT is the average time (days); SA is the area of exposed skin $\left(\mathrm{cm}^{2}\right) ; \mathrm{K}_{\mathrm{p}}$ is the dermal permeability coefficient for each heavy metal in water $(\mathrm{cm} / \mathrm{h})$; ET is the exposure time ( $\mathrm{h} /$ day); $\mathrm{ABS}_{\mathrm{GI}}$ is the gastrointestinal absorption factor. The above parameters are from the United States Environmental Protection Agency (EPA) (EPA 2004).

\section{Water quality index}

The WQI is calculated as follows:

$$
W Q I=\sum\left[W_{i} \times\left(C_{i} / S_{i}\right)\right] \times 100
$$

where $W_{i}$ is the weight of each element and represents different contributions to the overall water quality, which is calculated by the eigenvalues for each principal component and factor 
159 loading for each heavy metal from the PCA results. $C_{i}$ is the concentration of each heavy metal

160 tested in this study. $S_{i}$ represents the limit value of drinking water for each heavy metal.

161 According to the WQI values, water quality can be classified into five categories as excellent

162 water (WQI $<50)$, good water $(50 \leq \mathrm{WQI}<100)$, poor water $(100 \leq \mathrm{WQI}<200)$, very poor

163 water $(200 \leq \mathrm{WQI}<300)$ and undrinkable water $(\mathrm{WQI} \geq 300)$. V and $\mathrm{Sr}$ are excluded from the

164 WQI calculations due to the lack of official drinking water guidelines.

165

166

167

168

169

170

171

172

173

174

175

176

177

178

179

180

181

182

183

184

185

186

187

188

189

190

191

192

193

194

195

196

197

\section{Results}

\section{Kolmogorov-Smirnov test of data}

Kolmogorov-Smirnov (K-S) statistics indicate most of the water parameters and heavy metals were in non-normal distribution (Table 1). Therefore, we reported the median concentrations instead of mean concentrations in our study.

\section{Physicochemical characteristics}

The physicochemical characteristics of water samples from the Lake Aha watershed are summarized in Table 1. Samples from three tributaries demonstrate slightly alkaline characteristics with a median $\mathrm{pH}$ value of 7.88 , varying from 6.71 to 8.64. Relatively, the median $\mathrm{pH}$ value of the Youyu River (7.64) is lower than the Baiyan River (8.05) and the Jinzhong River (7.96). The DO values range from 0.42 to $18.64 \mathrm{mg} / \mathrm{L}$, with a median of $9.59 \mathrm{mg} / \mathrm{L}$. The EC values range from 199.4 to $1437.0 \mu \mathrm{S} / \mathrm{cm}$, with a median of $584.8 \mu \mathrm{S} / \mathrm{cm}$. Overall, the $\mathrm{pH}$, DO and EC values in the Lake Aha watershed show a noticeable variability.

\section{Heavy metals content}

The concentrations of dissolved heavy metals are also summarized in Table 1. According to their concentrations, these heavy metals can be divided into three groups: (1) Sr is in the highest level, with a median concentration of $>100 \mu \mathrm{g} / \mathrm{L}$; (2) Fe, Ba, Al, Ni and Sb are in intermediate levels, with median concentrations ranging from 1 to $100 \mu \mathrm{g} / \mathrm{L}$; (3) $\mathrm{Mn}, \mathrm{V}$ and Co are in low level, with median concentrations of $<1 \mu \mathrm{g} / \mathrm{L}$.

Table 2 shows the comparison of heavy metals concentrations between this study and the guideline values for drinking water set by China EPA (2006), US EPA (2004), and World Health Organization (WHO) (2006). The guideline values set by China EPA (2006) are the strictest and most comprehensive of the three. Thus, we used Chinese guideline values as the standard to evaluate water quality in this study. The median concentrations of nine heavy metals in this study are within limited values of drinking water guidelines (except V and Sr, without limited values in three guidelines), indicating the water is not heavily polluted by these heavy metals. However, for specific metals, their concentrations exceed the limit values at some sites (e.g., Mn at YR-5, $\mathrm{Sb}$ at BR-14). This indicates that these sites can attribute to a relatively high anthropogenic input. Besides, if the concentration of one sampling site is higher than other sampling sites (even if 
198 lower than guideline values), such as the Al concentrations in YR-5, it may also reveal an impact 199 of anthropogenic input.

\section{Discussion}

\section{Comparison and distribution of heavy metals in tributaries}

In the low flow season, the temporal distribution of each heavy metals in tributaries is shown in Fig. 2. In general, the Al and Mn concentrations showed an increasing trend with time, whereas the $\mathrm{Sb}$ and $\mathrm{Ba}$ concentrations displayed a decreasing trend. Meanwhile, the trends of the same heavy metal between three tributaries could be different. For example, the Co concentration of the Jinzhong River increased with time in contrast to the stable trend in the other tributaries, and Ni concentrations of the Youyu River and the Jinzhong River was higher in November and December while Baiyan River did not change obviously. It is noteworthy that the Jinzhong River showed more significant variation than the Youyu River and Baiyan River, perhaps due to the small number of sampling sites $(n=3)$ on the Jinzhong River.

The spatial distribution of heavy metals in three tributaries is shown in Fig.3. Spatial distributions of heavy metals displayed an extensive variation, and we could conclude three primary patterns based on the spatial distribution features: (1) Al, Mn, Co and Ni, their concentrations increased in the middle reaches of the Youyu River. (2) Fe and Sr, their concentrations were higher in Youyu River but occurred valley values in the upstream. (3) Ba, V and $\mathrm{Sb}$, their concentrations were consistently low in the Youyu River but relatively high value in the other two tributaries.

Different anthropogenic activities may explain the distinction on dissolved heavy metals among three tributaries. The lowest $\mathrm{pH}$ value in the Youyu River exhibited an influence of acid mine drainage. The Jinzhong River was the most typical urban tributary impacted by human activities in our study, and the Jinyang Wastewater Treatment Plant with limited capacity and damaged sewer networks provided an amount of pollutant input (Huang et al. 2009; Song et al. 2011; Zhang et al. 2019). The peak value in BR-14 (a groundwater well) could attribute to the contamination of domestic sewage through karst conduits.

We compare our results with previous results of the upstream of Xijiang River (Beipan River and Nanpan River), Guizhou, China and the world average concentrations (Li 1982; Liu et al. 2017) (Table 2). The Ni, Sb and Sr concentrations of our study were higher than the worldwide river average concentrations, while $\mathrm{Co}$ and Fe concentrations were comparable. $\mathrm{Mn}, \mathrm{Co}, \mathrm{Ba}, \mathrm{V}$ and $\mathrm{Sb}$ concentrations were comparable to that in the upstream of Xijiang River, but the $\mathrm{Sr}$ concentration in both sites was much higher than the worldwide river average. Notably, the geological background of the upstream of Xijiang River was consistent with our study site, indicating that the bedrock lithology, as a way of natural source, could significantly affect 
238

239

240

241

242

243

244

245

246

247

248

249

250

251

252

253

254

255

256

257

258

259

260

261

262

263

264

265

266

267

268

269

270

271

272

273

274

275

276

277

might be higher than that in other regions (Han \& Liu 2006; Han et al. 2019; Peng et al. 2012; Zeng et al. 2020).

\section{Potential source identification Correlation analysis}

We used Spearman's correlation to explore the associations and interactions of nine dissolved heavy metals and physicochemical characteristics in three tributaries. The results are presented in Table 3. The $\mathrm{pH}$ is an important factor affecting the dissolved heavy metal contents in water. The lower $\mathrm{pH}$ can increase the competition between metals and hydrogen ions for binding sites and may dissolve metal-carbonate complexes in sediments, releasing free metals (Papafilippaki et al. 2008). As shown in Table $3, \mathrm{pH}$ was significant positive correlated $(\mathrm{p}<0.01)$ with $\mathrm{Al}(0.383), \mathrm{V}$ (0.247), Sb (0.339), while Mn (-0.299), Fe (-0.399) and $\mathrm{Sr}(-0.303)$ were significant negative correlated $(\mathrm{p}<0.01)$ with $\mathrm{pH}$. The results indicated that $\mathrm{pH}$ played a crucial role for the dissolved heavy metals in three tributaries (except $\mathrm{Co}, \mathrm{Ni}$ and $\mathrm{Ba}$ ). In addition to $\mathrm{pH}$, the source is considered to be the most vital factor in the temporal-spatial distribution of heavy metals in water, which is integrated by a natural source and anthropogenic source (Li \& Zhang 2010; Liu et al. 2017). EC, as a measure of total dissolved ions in water, is largely a function of basin biogeochemistry and land use. Increases in EC might be accompanied by elevated dissolved heavy metals in water (Walker \& Pan 2006). Therefore, distinguishing the effects of natural and anthropogenic sources of variability in conductivity is important for identifying the potential sources for dissolved heavy metals. EC was strong positive correlation $(\mathrm{p}<0.01)$ with $\mathrm{Mn}$ (0.295), Co (0.336), Ni (0.552), Fe (0.633) and Sr (0.679) in our study. For dissolved heavy metals, strong positive correlations indicated that different heavy metals might have similar sources, migration and conversion behaviors (Wang et al. 2017). Strong positive correlations ( $p$ $<0.01$ ) were observed ranging from 0.274 to 0.602 between each pair of $\mathrm{Mn}, \mathrm{Co}, \mathrm{Ni}, \mathrm{Fe}$ and $\mathrm{Sr}$. Co was positively correlated with most elements (except $\mathrm{Sb}$ ), indicating that Co could have multiple sources in the Lake Aha watershed. Moreover, $\mathrm{Ba}, \mathrm{V}$ and $\mathrm{Sb}$ were observed of pairwise strong correlations $(\mathrm{p}<0.01)$, indicating that they had similar sources.

\section{Principal component analysis}

Principal component analysis (PCA) is applied for nine heavy metals in three tributaries to identify their possible sources. The Kaiser-Meyer-Olkin (KMO) value and Bartlett's sphericity test are respectively 0.69 and zero, indicating that the data in this study is suitable for PCA. Three principal components (PCs) extracted from the element were shown in Table 4 and Fig.4, accounting for $74.74 \%$ of the total variance.

The PC 1 explained $34.58 \%$ of the total variance and had a high loading of Mn (0.96), Co (0.95), $\mathrm{Al}(0.79)$ and $\mathrm{Ni}(0.74)$. The concentrations of these four heavy metals occurred an increase in the middle reaches of YR, where most of the abandoned coal mining was located (Bai et al. 2007; Bangjiang et al. 2014; Pan et al. 2019). Hence, the PC 1 with high loadings on Mn, Co, Al 
278

279

280

281

282

283

284

285

286

287

288

289

290

291

292

293

294

295

296

297

298

299

300

301

302

303

304

305

306

307

308

309

310

311

312

313

314

315

316

317

and Ni might be dominantly influenced by acid coal mine drainage (Abraham et al. 2018; Ali et al. 2017; Santelli et al. 2010; Seo et al. 2017; Tiwary 2001). The PC 2, accounting for $22.61 \%$ of the total variance and predominantly contained $\mathrm{Ba}(0.88), \mathrm{V}(0.84)$ and $\mathrm{Sb}(0.64)$, where the concentrations matched well with the upper Xijiang River (Liu et al. 2017). Among three tributaries, $\mathrm{Ba}, \mathrm{V}$ and $\mathrm{Sb}$ show higher concentrations in BR and JR than YR. Previous investigation and the scene observation found that BR and JR are influenced by human activities more than YR, with a higher percentage of residential and commercial land (Huang et al. 2009; Song et al. 2011; Zhang et al. 2019). Considering that Ba, V and Sb are widely used in industrial and medical (Filella et al. 2002; Hope 2008; Kravchenko et al. 2014; Wilson et al. 2010), these heavy metals could be attributed to anthropogenic sources. The PC 3 had strong loadings of Fe (0.85) and $\mathrm{Sr}(0.78)$, with a variance of $17.55 \%$. Fe is a major element in Earth's crust (Wang et al. 2017), therefore the high concentrations of $\mathrm{Sr}$ (much higher than the world average and consistent with the background value) may be originated from carbonate weathering (Liu et al. 2017). Therefore, PC 3 could be attributed to the sources of geologic origins.

\section{Water Quality Index and Health Risk Assessment}

According to PCA, the weights of each heavy metal are shown in Table 5. The WQI values of each sampling site were calculated with Eq. (6) and shown in Fig.5. The WQI values varied from 3.12 to 15.64 , with an average of 5.79. YR-5 (WQI = 15.64) was the only site of which the WQI value exceeded 10 , regarded as a relatively high site. Therefore, all the water samples could be defined as excellent water quality (WQI $<50$ ), indicating that the natural water in tributaries was suitable for drinking with respect to heavy metals pollution.

According to Eqs. (2) - (6), the HQ and HI values of heavy metals for adults and children by ingestion and dermal pathways are calculated and summarized in Table 6. All HQingestion,

$\mathrm{HQ}_{\text {dermal }}$ and $\mathrm{HI}$ values are far smaller than 1, indicating these dissolved heavy metals in the Lake Aha watershed only make a little hazard for adults and children via ingestion and dermal absorption. Compared to dermal, ingestion is the primary pathway to endanger humans for these dissolved heavy metals. The HI value of Sb for children (0.154) is the only value exceeding 0.1 . Consequently, Sb might be a potential non-carcinogenic risk to human health. It is worth noting that the HQ and HI values for children are higher than that for adults, suggesting that children are at higher risk than adults under the exposure of heavy metals.

\section{Conclusions}

The heavy metal concentrations in the Lake Aha watershed displayed both temporal and spatial variations. The Jinzhong River showed more obvious temporal variation than the Youyu River and the Baiyan River, and nine heavy metals could be classified into three spatial distribution patterns due to their features: (1) Al, Mn, Co and Ni; (2) Fe and Sr; (3) Ba, V and Sb. Sr was the most abundant heavy metals and the only element of which concentration exceeding $100 \mu \mathrm{g} / \mathrm{L}$. The PCA results indicated that the acid coal mine drainage might influence $\mathrm{Mn}, \mathrm{Co}, \mathrm{Al}$ and Ni 
concentrations, and $\mathrm{Ba}, \mathrm{V}$ and $\mathrm{Sb}$ could be attributed to anthropogenic activities of industrial and medical, and Fe and Sr mainly presented a natural geological feature in the study area. The heavy metal concentrations in most sampling sites were within the limited values for the Chinese drinking water guideline, and the water quality indicated that the waters in three tributaries were not polluted by the nine heavy metals. Overall, the water quality of the Lake Aha watershed is good, however risk assessment suggested that $\mathrm{Sb}$ had a relatively higher hazard index, suggesting a potential risk. Children were under a higher risk than adults, while the ingestion was the primary exposure pathway. To explore the behaviors of heavy metals during water/particle interaction, there is a need for further research including the behavior in suspended particulate matter and the heavy metals speciation analysis in future research.

\section{Acknowledgments}

We thank Huipeng Jia and Yuanyi Shen from Guizhou University for sample analyses.

\section{References}

Abraham J, Dowling K, and Florentine S. 2018. Assessment of potentially toxic metal contamination in the soils of a legacy mine site in Central Victoria, Australia. Chemosphere 192:122-132. 10.1016/j.chemosphere.2017.10.150

Ali A, Strezov V, Davies P, and Wright I. 2017. Environmental impact of coal mining and coal seam gas production on surface water quality in the Sydney basin, Australia. Environmental Monitoring and Assessment 189:408. 10.1007/s10661-017-6110-4

Ariffin N, Abdullah MMAB, Mohd Arif Zainol MRR, Murshed MF, Hariz Z, Faris MA, and Bayuaji R. 2017. Review on Adsorption of Heavy Metal in Wastewater by Using Geopolymer. MATEC Web of Conferences 97:01023. 10.1051/matecconf/20179701023

Bai W, Feng X, Jin Z, Sun L, and Yan H. 2007. The Influence of Rivers on The Transport And Fate of mercury Species in the Aha Reservoir. Acta Mineralogica Sinica 02:218-224. 10.16461/j.cnki

Bangjiang L, Longchang w, Mingzhong 1, Xiaoyu z, and Xiaoli Y. 2014. Evaluation of Coal Mining Waste land Polluted by Heavy Metal of Huaxi. Guizhou Agricultural Sciences 42:130-135.

Burakov AE, Galunin EV, Burakova IV, Kucherova AE, Agarwal S, Tkachev AG, and Gupta VK. 2018. Adsorption of heavy metals on conventional and nanostructured materials for wastewater treatment purposes: A review. Ecotoxicol Environ Saf 148:702-712. 10.1016/j.ecoenv.2017.11.034

Cameron H, Mata MT, and Riquelme C. 2018. The effect of heavy metals on the viability of Tetraselmis marina AC16-MESO and an evaluation of the potential use of this microalga in bioremediation. Peerj 6. 10.7717/peerj.5295

EPA A. 2004. Risk Assessment Guidance for Superfund. Volume I: Human Health Evaluation Manual (Part E, Supplemental Guidance for Dermal Risk Assessment). EPA/540/R/99.

Filella M, Belzile N, and Chen Y-W. 2002. Antimony in the environment: a review focused on natural waters: I. Occurrence. Earth-Science Reviews 57:125-176. https://doi.org/10.1016/S0012-8252(01)00070-8 
360

361

362

363

364

365

366

367

368

369

370

371

372

373

374

375

376

377

378

379

380

381

382

383

384

385

386

387

388

389

390

391

392

393

394

395

396

397

398

399

400

401

402

403

404

405

Han G, and Liu C-Q. 2004. Water geochemistry controlled by carbonate dissolution: a study of the river waters draining karst-dominated terrain, Guizhou Province, China. Chemical Geology 204:1-21. https://doi.org/10.1016/j.chemgeo.2003.09.009

Han G, and Liu C-Q. 2006. Strontium isotope and major ion chemistry of the rainwaters from Guiyang, Guizhou Province, China. Science of the Total Environment 364:165-174. https://doi.org/10.1016/j.scitotenv.2005.06.025

Han G, Song Z, Tang Y, Wu Q, and Wang Z. 2019. Ca and Sr isotope compositions of rainwater from Guiyang city, Southwest China: Implication for the sources of atmospheric aerosols and their seasonal variations. Atmospheric Environment 214:116854. https://doi.org/10.1016/j.atmosenv.2019.116854

Han G, Tang Y, and Xu Z. 2010. Fluvial geochemistry of rivers draining karst terrain in Southwest China. Journal of Asian Earth Sciences 38:65-75. 10.1016/j.jseaes.2009.12.016

Hope BK. 2008. A dynamic model for the global cycling of anthropogenic vanadium. 22. $10.1029 / 2008 \mathrm{gb} 003283$

Huang X-f, Hu J-w, Deng J-j, Li C-x, and Qin F-x. 2009. Speciation of heavy metals in sediments from Baihua Lake and Aha Lake. Asia-Pacific Journal of Chemical Engineering 4:635-642. 10.1002/apj.307

Islam MS, Ahmed MK, Raknuzzaman M, Habibullah -Al- Mamun M, and Islam MK. 2015. Heavy metal pollution in surface water and sediment: A preliminary assessment of an urban river in a developing country. Ecological Indicators 48:282-291. 10.1016/j.ecolind.2014.08.016

Kravchenko J, Darrah TH, Miller RK, Lyerly HK, and Vengosh A. 2014. A review of the health impacts of barium from natural and anthropogenic exposure. Environ Geochem Health 36:797-814. 10.1007/s10653-014-9622-7

Krishna AK, Satyanarayanan M, and Govil PK. 2009. Assessment of heavy metal pollution in water using multivariate statistical techniques in an industrial area: a case study from Patancheru, Medak District, Andhra Pradesh, India. J Hazard Mater 167:366-373. 10.1016/j.jhazmat.2008.12.131

Li S, and Zhang Q. 2010. Spatial characterization of dissolved trace elements and heavy metals in the upper Han River (China) using multivariate statistical techniques. Journal of Hazardous Materials 176:579-588. 10.1016/j.jhazmat.2009.11.069

Li Y-H. 1982. A brief discussion on the mean oceanic residence time of elements. Geochimica Et Cosmochimica Acta 46:2671-2675. 10.1016/0016-7037(82)90386-6

Liu J, Li S-L, Chen J-B, Zhong J, Yue F-J, Lang Y, and Ding H. 2017. Temporal transport of major and trace elements in the upper reaches of the Xijiang River, SW China. Environmental Earth Sciences 76. 10.1007/s12665-017-6625-6

Loska K, and Wiechuła D. 2003. Application of principal component analysis for the estimation of source of heavy metal contamination in surface sediments from the Rybnik Reservoir. Chemosphere 51:723-733. https://doi.org/10.1016/S0045-6535(03)00187-5

Meng Q, Zhang J, Zhang Z, Wu TJES, and Research P. 2016. Geochemistry of dissolved trace elements and heavy metals in the Dan River Drainage (China): distribution, sources, and water quality assessment. Environmental Science and Pollution Research 23:8091-8103. 10.1007/s11356-016-6074-x

Nguyen TC, Loganathan P, Nguyen TV, Kandasamy J, Naidu R, and Vigneswaran S. 2018. Adsorptive removal of five heavy metals from water using blast furnace slag and fly ash.

Peer) reviewing PDF | (2020:03:46588:1:1:NEW 29 Jun 2020) 
406

407

408

409

410

411

412

413

414

415

416

417

418

419

420

421

422

423

424

425

426

427

428

429

430

431

432

433

434

435

436

437

438

439

440

441

442

443

444

445

446

447

448

449

450

Environmental Science and Pollution Research 25:20430-20438. 10.1007/s11356-0179610-4

Nriagu JO. 1989. A global assessment of natural sources of atmospheric trace metals. Nature 338:47-49. 10.1038/338047a0

Pan L, Muxinjian L, Yiyu C, Shuiting L, Zhidong X, and Guangle Q. 2019. Exposure risk and Cadmium content in Spiders Dwelling in Major Reservoir Areas of the Guiyang City. Earth and Environment 04:510-517. 10.14050/j.cnki.1672-9250.2019.47.069

Papafilippaki A, Kotti M, and Stavroulakis G. 2008. Seasonal Variations in Dissolved Heavy Metals in the Keritis River, Chania, Greece. GlobalNEST International Journal 10:320325.

Pekey H, Karakaş D, and Bakog `lu M. 2004. Source apportionment of trace metals in surface waters of a polluted stream using multivariate statistical analyses. Marine Pollution Bulletin 49:809-818. https://doi.org/10.1016/j.marpolbul.2004.06.029

Peng H, Ma C, Xia Y, Li Z, and Wan J. 2012. Geochemical characteristics of main ions and $\mathrm{Sr}$ and the heavymetal contamination in the tributary channel of MaopingRiver in TGP Reservoir Area. Geotechnical Investigation and surveying 12.

Rehman K, Fatima F, Waheed I, and Akash MSH. 2018. Prevalence of exposure of heavy metals and their impact on health consequences. $J$ Cell Biochem 119:157-184. $10.1002 / \mathrm{jcb} .26234$

Santelli CM, Pfister DH, Lazarus D, Sun L, Burgos WD, and Hansel CM. 2010. Promotion of $\mathrm{Mn}(\mathrm{II})$ Oxidation and Remediation of Coal Mine Drainage in Passive Treatment Systems by Diverse Fungal and Bacterial Communities. Applied and Environmental Microbiology 76:4871-4875. 10.1128/aem.03029-09

Seo EY, Cheong YW, Yim GJ, Min KW, and Geroni JN. 2017. Recovery of Fe, Al and Mn in acid coal mine drainage by sequential selective precipitation with control of $\mathrm{pH}$. Catena 148:11-16. 10.1016/j.catena.2016.07.022

Song L, Liu C-Q, Wang Z-L, Zhu X, Teng Y, Liang L, Tang S, and Li J. 2011. Iron isotope fractionation during biogeochemical cycle: Information from suspended particulate matter (SPM) in Aha Lake and its tributaries, Guizhou, China. Chemical Geology 280:170-179. 10.1016/j.chemgeo.2010.11.006

Sun J, Takahashi Y, Strosnider WHJ, Kogure T, Wu P, and Cao X. 2019. Tracing and quantifying contributions of end members to karst water at a coalfield in southwest China. Chemosphere 234:777-788. 10.1016/j.chemosphere.2019.06.066

Taş B, Tepe Y, Ustaoğlu F, and Alptekin S. 2019. Benthic algal diversity and water quality evaluation by biological approach of Turnasuyu Creek, NE Turkey. DESALINATION AND WATER TREATMENT 155:402-415. 10.5004/dwt.2019.24225

Tiwary RK. 2001. Environmental Impact of Coal Mining on Water Regime and Its Management. 132:185- 199.

Ustaoğlu F, and Tepe Y. 2019. Water quality and sediment contamination assessment of Pazarsuyu Stream, Turkey using multivariate statistical methods and pollution indicators. International Soil and Water Conservation Research 7:47-56. 10.1016/j.iswcr.2018.09.001

Ustaoğlu F, Tepe Y, and Aydin H. 2020a. Heavy metals in sediments of two nearby streams from Southeastern Black Sea coast: Contamination and ecological risk assessment. Environmental Forensics 21:145-156. 10.1080/15275922.2020.1728433 
451

452

453

454

455

456

457

458

459

460

461

462

463

464

465

466

467

468

469

470

471

472

473

474

475

476

477

478

479

480

481

482

483

484

485

486

487

488

489

490

491
Ustaoğlu F, Tepe Y, Aydin H, and Akbas A. 2020b. EVALUATION OF SURFACE WATER QUALITY BY MULTIVARIATE STATISTICAL ANALYSES AND WQI: CASE OF COMLEKCI STREAM, (GIRESUN-TURKEY). Fresenius Environmental Bulletin 29:167-177.

Ustaoğlu F, Tepe Y, and Taş B. 2020c. Assessment of stream quality and health risk in a subtropical Turkey river system: A combined approach using statistical analysis and water quality index. Ecological Indicators 113:105815. 10.1016/j.ecolind.2019.105815

Varol M. 2011. Assessment of heavy metal contamination in sediments of the Tigris River (Turkey) using pollution indices and multivariate statistical techniques. J Hazard Mater 195:355-364. 10.1016/j.jhazmat.2011.08.051

Vörösmarty CJ, McIntyre PB, Gessner MO, Dudgeon D, Prusevich A, Green P, Glidden S, Bunn SE, Sullivan CA, Liermann CR, and Davies PM. 2010. Global threats to human water security and river biodiversity. Nature 467:555-561. 10.1038/nature09440

Walker CE, and Pan Y. 2006. Using Diatom Assemblages to Assess Urban Stream Conditions. Hydrobiologia 561:179-189. 10.1007/s10750-005-1613-3

Wang J, Liu G, Liu H, and Lam PKS. 2017. Multivariate statistical evaluation of dissolved trace elements and a water quality assessment in the middle reaches of Huaihe River, Anhui, China. Sci Total Environ 583:421-431. 10.1016/j.scitotenv.2017.01.088

Wilson SC, Lockwood PV, Ashley PM, and Tighe M. 2010. The chemistry and behaviour of antimony in the soil environment with comparisons to arsenic: A critical review. Environmental Pollution 158:1169-1181. https://doi.org/10.1016/j.envpol.2009.10.045

Wu B, Zhao DY, Jia HY, Zhang Y, Zhang XX, and Cheng SP. 2009. Preliminary risk assessment of trace metal pollution in surface water from Yangtze River in Nanjing Section, China. Bull Environ Contam Toxicol 82:405-409. 10.1007/s00128-008-9497-3

Xiao J, Wang L, Deng L, and Jin Z. 2019. Characteristics, sources, water quality and health risk assessment of trace elements in river water and well water in the Chinese Loess Plateau. Sci Total Environ 650:2004-2012. 10.1016/j.scitotenv.2018.09.322

Zeng J, Han G, Wu Q, and Tang Y. 2019a. Geochemical characteristics of dissolved heavy metals in Zhujiang River, Southwest China: spatial-temporal distribution, source, export flux estimation, and a water quality assessment. Peerj 7:e6578. 10.7717/peerj.6578

Zeng J, Han G, Wu Q, and Tang Y. 2019b. Heavy Metals in Suspended Particulate Matter of the Zhujiang River, Southwest China: Contents, Sources, and Health Risks. Int J Environ Res Public Health 16. 10.3390/ijerph16101843

Zeng J, Han G, Wu Q, and Tang Y. 2020. Effects of agricultural alkaline substances on reducing the rainwater acidification: Insight from chemical compositions and calcium isotopes in a karst forests area. Agriculture, Ecosystems \& Environment 290. 10.1016/j.agee.2019.106782

Zhang J, Wang Z, Wu Q, An Y, Jia H, and Shen Y. 2019. Anthropogenic Rare Earth Elements: Gadolinium in a Small Catchment in Guizhou Province, Southwest China. International Journal of Environmental Research and Public Health 16. 10.3390/ijerph16204052 
Figure 1

Sampling sites in the tributaries of Lake Aha.

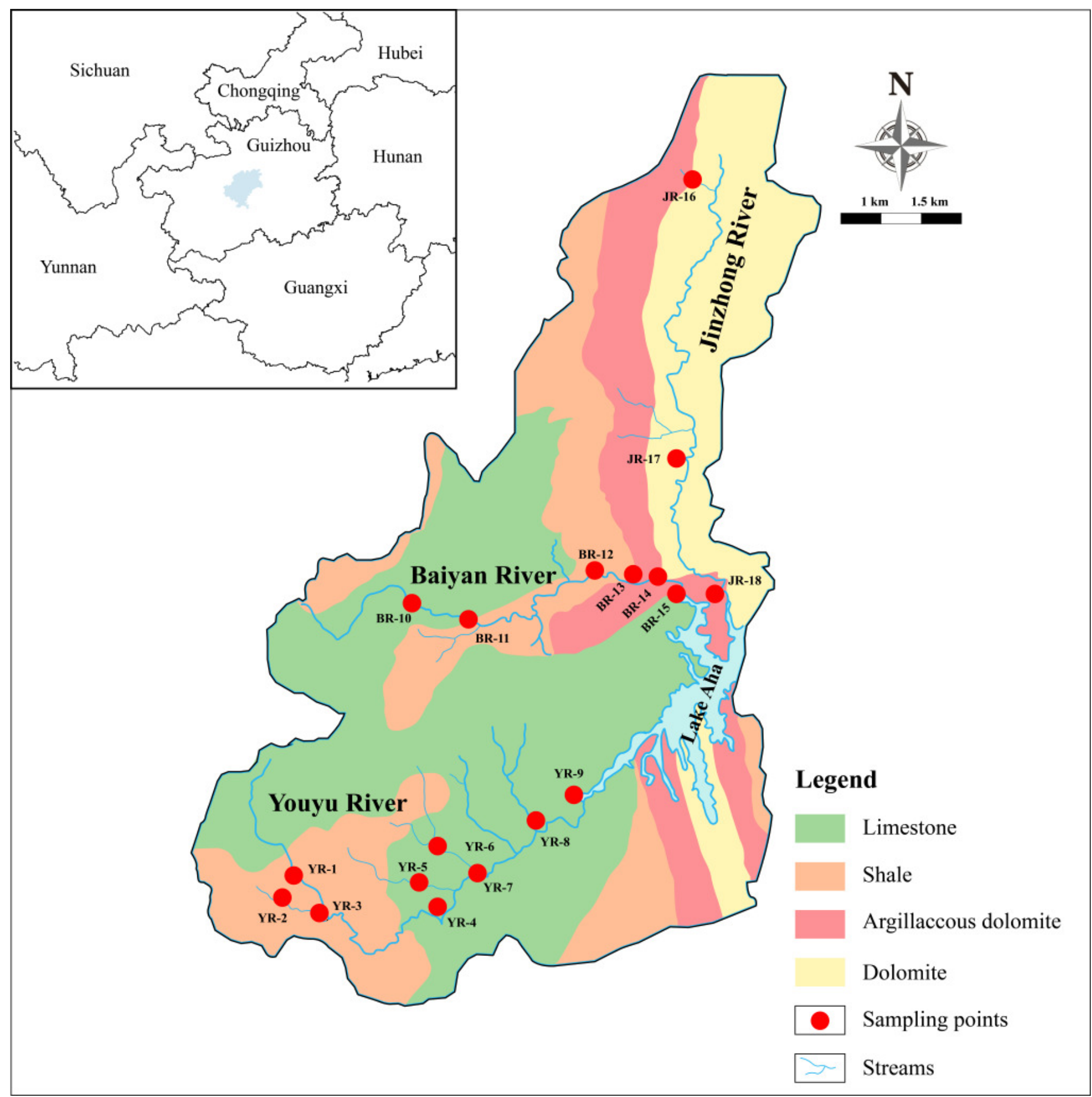


Figure 2

Temporal distributions of dissolved heavy metals in three tributaries of Lake Aha.

YR, Youyu River; BR, Baiyan River; JR, Jinzhong River. The vertical dash line divides the different tributaries. (A) Al concentrations. (B) V concentrations. (C) Mn concentrations. (D) Fe concentrations. (E) Co concentrations. (F) Ni concentrations. (G) Sr concentrations. (H) Sb concentrations. (I) Ba concentrations.
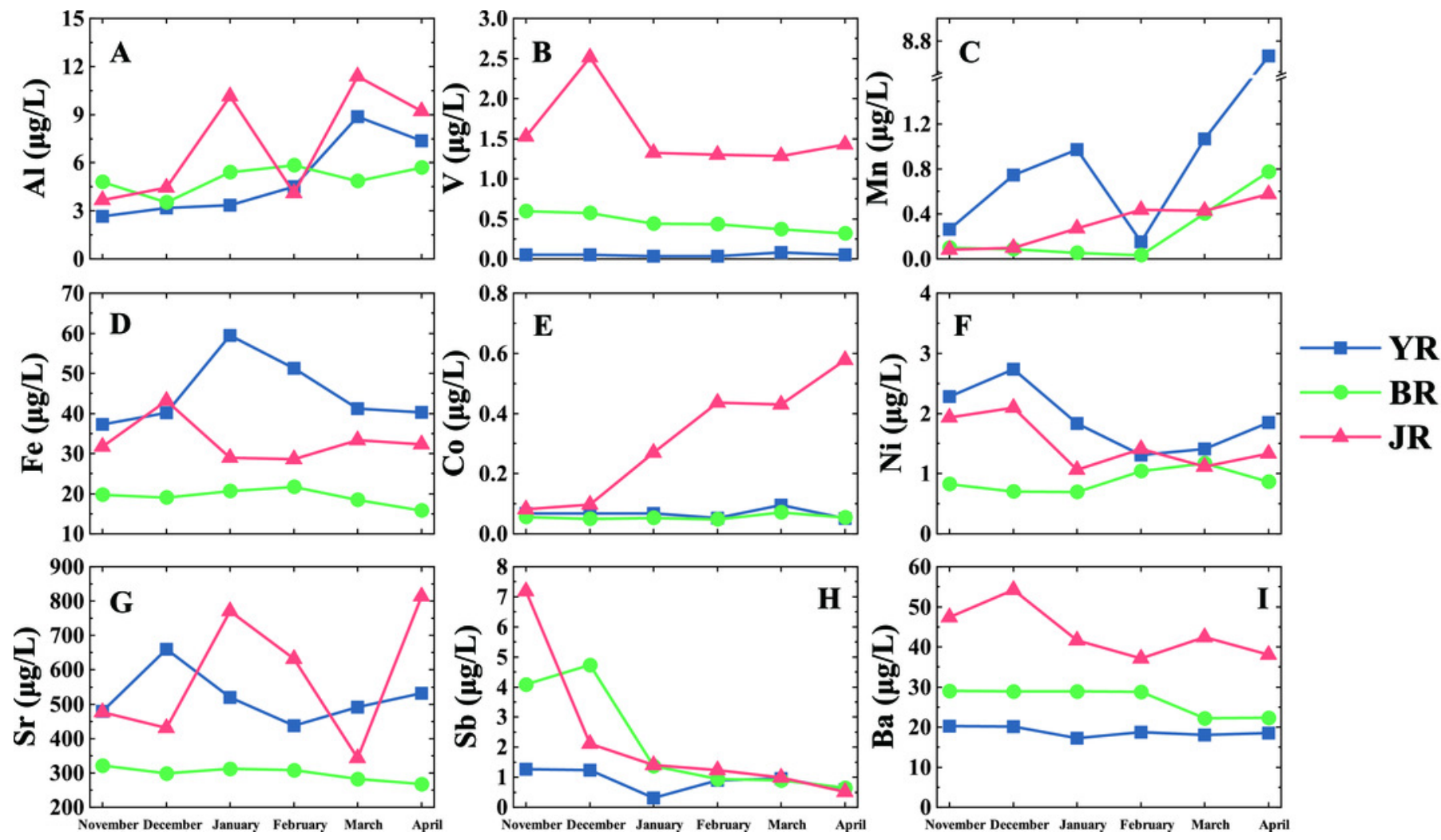
Figure 3

Spatial distributions of dissolved heavy metals in three tributaries of Lake Aha.

YR, Youyu River; BR, Baiyan River; JR, Jinzhong River. The vertical dash line divides the different tributaries.
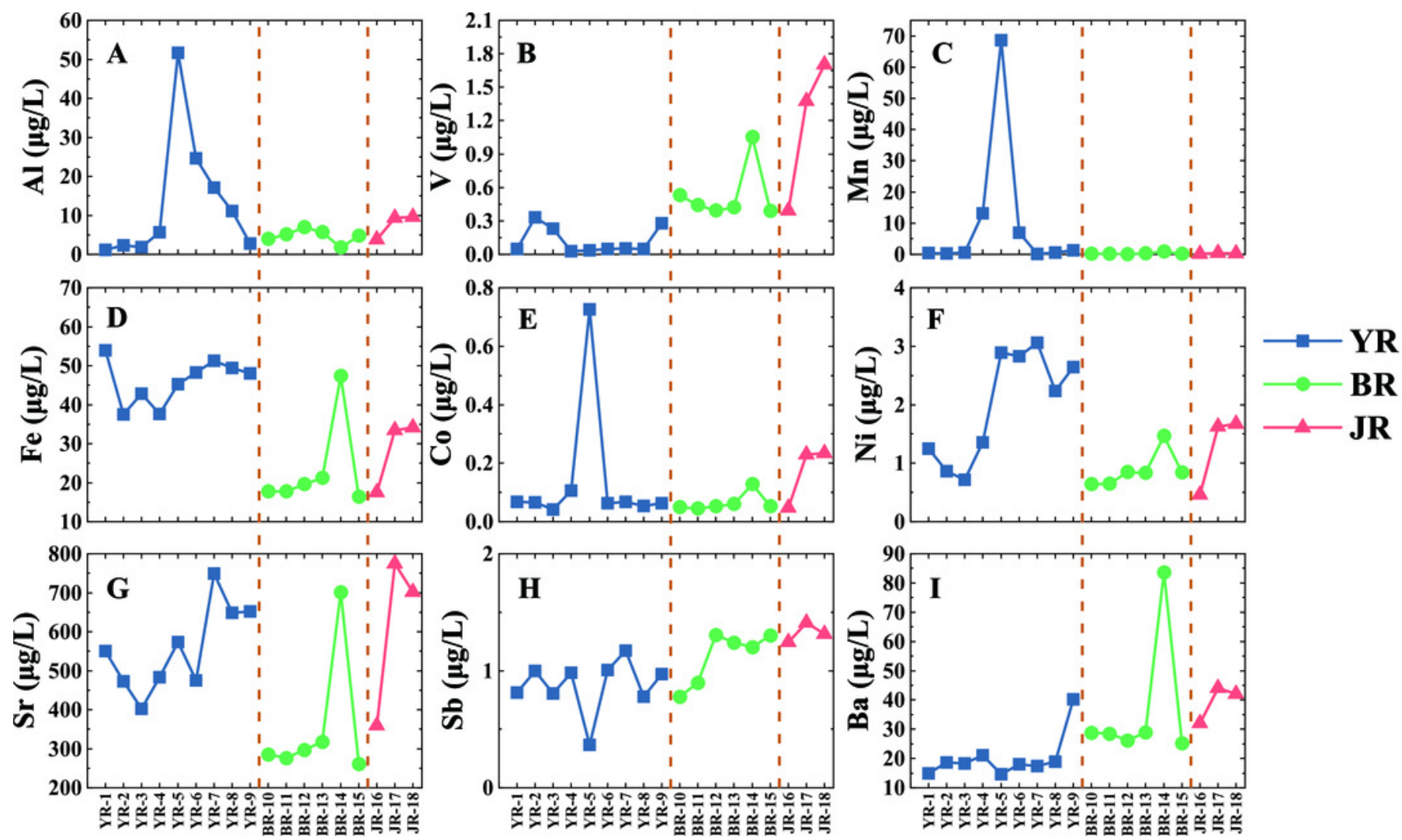
Figure 4

Loading plot of factors or dissolved heavy metals in the tributaries of Lake Aha.

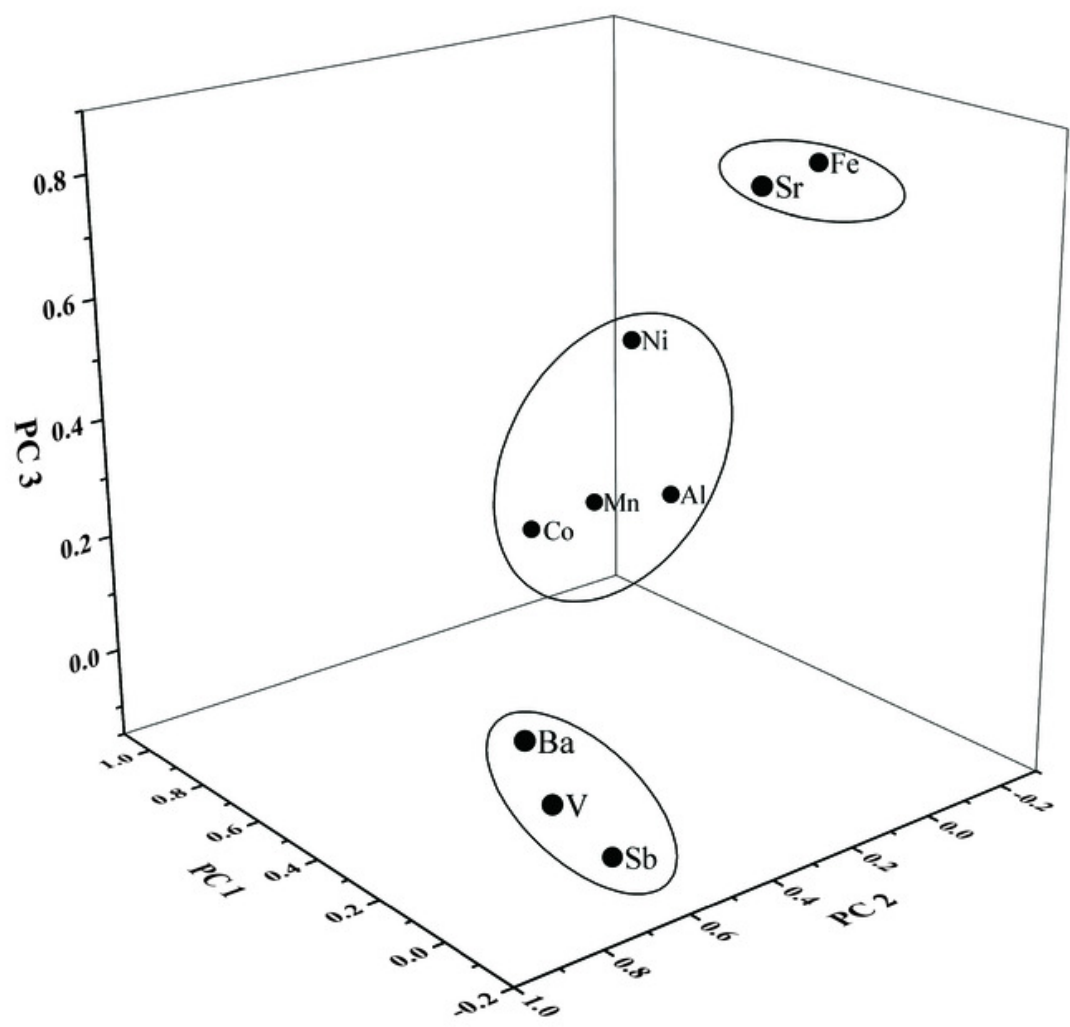


Figure 5

WQI values of water in three tributaries of Lake Aha.

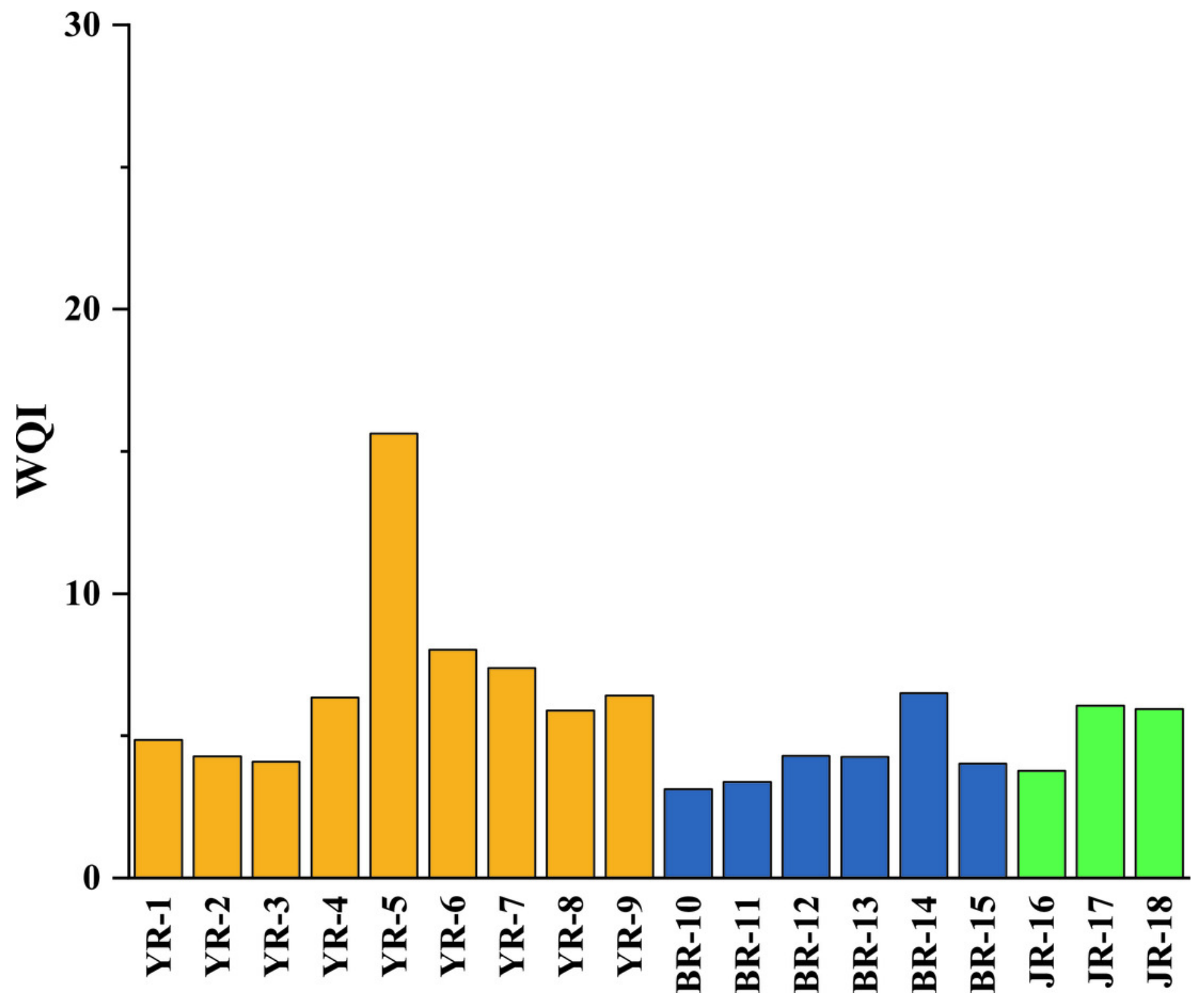




\section{Table $\mathbf{1}$ (on next page)}

Concentrations of dissolved heavy metals, $\mathrm{pH}$, dissolved oxygen and electric conductivity in Lake Aha. 


\begin{tabular}{|c|c|c|c|c|c|c|c|c|c|c|c|c|c|}
\hline Tributaries & & pH & DO & EC & Mn & Co & Al & $\mathbf{N i}$ & Ba & $\mathbf{V}$ & Sb & $\mathrm{Fe}$ & $\mathrm{Sr}$ \\
\hline & & & $\mathrm{mg} / \mathrm{L}$ & $\mu \mathrm{S} / \mathrm{cm}$ & $\mu \mathrm{g} / \mathrm{L}$ & $\mu \mathrm{g} / \mathrm{L}$ & $\mu \mathrm{g} / \mathrm{L}$ & $\mu \mathrm{g} / \mathrm{L}$ & $\mu \mathrm{g} / \mathrm{L}$ & $\mu \mathrm{g} / \mathrm{L}$ & $\mu \mathrm{g} / \mathrm{L}$ & $\mu \mathrm{g} / \mathrm{L}$ & $\mu \mathrm{g} / \mathrm{L}$ \\
\hline \multirow[t]{6}{*}{ Youyu River } & Max & 8.62 & 18.64 & 1437.0 & 145.261 & 2.35 & 167.08 & 10.91 & 44.73 & 0.79 & 9.11 & 116.1 & 923.93 \\
\hline & Min & 6.71 & 2.26 & 199.4 & 0.005 & 0.03 & 0.74 & 0.57 & 12.47 & 0.01 & 0.14 & 19.23 & 312.28 \\
\hline & Median & 7.64 & 9.84 & 604.0 & 0.777 & 0.07 & 4.19 & 1.92 & 18.87 & 0.05 & 0.89 & 42.62 & 515.91 \\
\hline & Mean & 7.62 & 9.32 & 737.2 & 16.458 & 0.25 & 17.17 & 2.68 & 20.96 & 0.16 & 1.06 & 48.48 & 539.36 \\
\hline & $\mathbf{S D}^{\mathrm{a}}$ & 0.44 & 2.84 & 268.5 & 35.509 & 0.53 & 31.30 & 2.40 & 7.51 & 0.17 & 1.31 & 18.44 & 170.15 \\
\hline & K-S test ${ }^{b}$ & 0.200 & 0.000 & 0.000 & 0.000 & 0.000 & 0.000 & 0.000 & 0.000 & 0.000 & 0.000 & 0.000 & 0.076 \\
\hline \multirow[t]{6}{*}{ Baiyan River } & Max & 8.42 & 10.85 & 1048.0 & 10.565 & 0.16 & 13.48 & 2.07 & 95.01 & 1.15 & 18.13 & 52.07 & 723.62 \\
\hline & Min & 6.74 & 0.42 & 366.0 & 0.005 & 0.03 & 1.00 & 0.38 & 17.36 & 0.22 & 0.29 & 10.69 & 167.45 \\
\hline & Median & 8.05 & 9.68 & 399.1 & 0.153 & 0.05 & 4.85 & 0.80 & 28.56 & 0.44 & 1.03 & 19.68 & 302.42 \\
\hline & Mean & 7.89 & 8.18 & 501.9 & 0.754 & 0.07 & 5.01 & 0.99 & 35.84 & 0.55 & 2.73 & 23.63 & 360.58 \\
\hline & SD & 0.48 & 3.66 & 227.5 & 1.877 & 0.04 & 2.70 & 0.46 & 22.64 & 0.28 & 3.81 & 11.97 & 165.07 \\
\hline & K-S test & 0.000 & 0.000 & 0.000 & 0.000 & 0.000 & 0.108 & 0.000 & 0.000 & 0.002 & 0.000 & 0.000 & 0.000 \\
\hline \multirow[t]{6}{*}{ Jinzhong River } & Max & 8.64 & 10.11 & 763.0 & 3.071 & 0.43 & 13.89 & 4.92 & 67.94 & 3.02 & 17.29 & 47.36 & 900.33 \\
\hline & Min & 7.48 & 5.93 & 362.4 & 0.046 & 0.03 & 1.94 & 0.37 & 24.39 & 0.30 & 0.45 & 9.50 & 178.49 \\
\hline & Median & 7.96 & 8.59 & 674.2 & 0.281 & 0.21 & 7.27 & 1.22 & 42.68 & 1.38 & 1.33 & 32.00 & 469.87 \\
\hline & Mean & 7.94 & 8.14 & 594.8 & 0.570 & 0.18 & 7.39 & 1.47 & 41.93 & 1.29 & 2.64 & 28.80 & 557.77 \\
\hline & SD & 0.27 & 1.22 & 148.37 & 0.85 & 0.12 & 3.78 & 1.14 & 9.72 & 0.78 & 4.00 & 10.30 & 229.47 \\
\hline & K-S test & 0.200 & 0.054 & 0.000 & 0.000 & 0.172 & 0.145 & 0.088 & 0.089 & 0.200 & 0.000 & 0.193 & 0.062 \\
\hline \multirow[t]{6}{*}{ Total } & $\operatorname{Max}$ & 8.64 & 18.64 & 1437.0 & 145.261 & 2.35 & 167.08 & 10.91 & 95.01 & 3.02 & 18.13 & 116.1 & 923.93 \\
\hline & Min & 6.71 & 0.42 & 199.4 & 0.005 & 0.03 & 0.74 & 0.37 & 12.47 & 0.01 & 0.14 & 9.50 & 167.45 \\
\hline & Median & 7.88 & 9.59 & 584.8 & 0.364 & 0.06 & 4.94 & 1.22 & 25.33 & 0.33 & 1.00 & 35.08 & 413.57 \\
\hline & Mean & 7.76 & 8.75 & 642.7 & 8.650 & 0.18 & 11.57 & 1.93 & 29.39 & 0.48 & 1.87 & 37.08 & 485.30 \\
\hline & SD & 0.45 & 2.97 & 261.7 & 26.352 & 0.39 & 22.97 & 1.94 & 16.80 & 0.56 & 2.96 & 19.22 & 198.11 \\
\hline & K-S test & 0.000 & 0.000 & 0.000 & 0.000 & 0.000 & 0.000 & 0.000 & 0.000 & 0.000 & 0.000 & 0.002 & 0.000 \\
\hline
\end{tabular}

\section{Notes:}

2 a Standard deviation.

$3{ }^{\mathrm{b}}$ Kolmogorov-Smirnov test. 


\section{Table 2 (on next page)}

Comparison of heavy metals in three tributaries of Lake Aha with drinking water guidelines, worldwide river average and Xijiang River. 


\begin{tabular}{|c|c|c|c|c|c|c|c|}
\hline & \multirow{2}{*}{$\begin{array}{l}\text { Study } \\
\text { Area }\end{array}$} & \multicolumn{3}{|c|}{ Drinking water guidelines } & \multirow{2}{*}{$\begin{array}{l}\text { World } \\
\text { River }^{d}\end{array}$} & \multirow{2}{*}{$\begin{array}{l}\text { Beipan } \\
\text { River }^{\mathrm{e}}\end{array}$} & \multirow{2}{*}{$\begin{array}{c}\text { Nanpan } \\
\text { River }^{\mathrm{e}}\end{array}$} \\
\hline & & China $^{a}$ & USEPA $^{\mathbf{b}}$ & WHO $^{\mathrm{c}}$ & & & \\
\hline & $\mu \mathrm{g} / \mathrm{L}$ & $\mu \mathrm{g} / \mathrm{L}$ & $\mu \mathrm{g} / \mathrm{L}$ & $\mu \mathrm{g} / \mathrm{L}$ & $\mu \mathrm{g} / \mathrm{L}$ & $\mu \mathrm{g} / \mathrm{L}$ & $\mu \mathrm{g} / \mathrm{L}$ \\
\hline $\mathrm{Mn}$ & 0.37 & 100 & & 400 & 7 & 0.30 & 0.30 \\
\hline $\mathrm{Co}$ & 0.06 & 1000 & & & 0.1 & 0.06 & 0.04 \\
\hline $\mathrm{Al}$ & 4.94 & 200 & & 200 & 50 & 10.8 & 11.7 \\
\hline $\mathrm{Ni}$ & 1.22 & 20 & & 70 & 0.3 & 0.34 & 0.27 \\
\hline $\mathrm{Ba}$ & 25.33 & 700 & 2000 & 700 & 20 & 25.4 & 25.1 \\
\hline $\mathrm{V}$ & 0.33 & & & & 0.9 & 0.78 & 0.77 \\
\hline $\mathrm{Sb}$ & 1.00 & 5 & & & 0.07 & 1.68 & 1.58 \\
\hline $\mathrm{Fe}$ & 35.08 & 300 & & 300 & 40 & & \\
\hline $\mathrm{Sr}$ & 413.57 & & & & 70 & 329 & 244 \\
\hline
\end{tabular}

1 Notes:

2 a China EPA drinking water standard (GB 5749-2006).

3 b US EPA drinking water standards (Water 2012).

$4{ }^{\mathrm{c}}$ WHO drinking water standards (Edition 2011).

$5 \quad{ }^{\mathrm{d}} \mathrm{Li}, 1982$.

$6 \quad$ e Liu et al., 2017.

7

8 


\section{Table 3 (on next page)}

Pearson correlation matrix of heavy metals and physicochemical parameters in the tributaries of Lake Aha. 


\begin{tabular}{|c|c|c|c|c|c|c|c|c|c|c|c|c|}
\hline & $\mathrm{Mn}$ & Co & $\mathrm{Al}$ & $\mathrm{Ni}$ & $\mathrm{Ba}$ & V & $\mathrm{Sb}$ & $\mathrm{Fe}$ & $\mathrm{Sr}$ & $\mathrm{pH}$ & $\mathrm{DO}$ & $\mathrm{EC}$ \\
\hline $\mathrm{Mn}$ & 1 & & & & & & & & & & & \\
\hline Co & $0.536 * *$ & 1 & & & & & & & & & & \\
\hline $\mathrm{Al}$ & $0.198 *$ & $0.239 *$ & 1 & & & & & & & & & \\
\hline $\mathrm{Ni}$ & $0.455 * *$ & $0.490 * *$ & $0.282 * *$ & 1 & & & & & & & & \\
\hline $\mathrm{Ba}$ & $-0.209 *$ & $0.199 *$ & $-0.214^{*}$ & -0.078 & 1 & & & & & & & \\
\hline $\mathrm{V}$ & $-0.289 * *$ & $0.210^{*}$ & $-0.231 *$ & $-0.284 * *$ & $0.719 * *$ & 1 & & & & & & \\
\hline $\mathrm{Sb}$ & $-0.406 * *$ & 0.063 & -0.14 & -0.107 & $0.424 * *$ & $0.437 * *$ & 1 & & & & & \\
\hline $\mathrm{Fe}$ & $0.337 * *$ & $0.291 * *$ & 0.024 & $0.641 * *$ & -0.174 & $-0.408 * *$ & -0.193 & 1 & & & & \\
\hline $\mathrm{Sr}$ & $0.274 * *$ & $0.377 * *$ & 0 & $0.487 * *$ & 0.05 & 0.015 & 0.016 & $0.602 * *$ & 1 & & & \\
\hline $\mathrm{pH}$ & $-0.299 * *$ & -0.059 & $0.383 * *$ & -0.083 & 0.083 & $0.247^{*}$ & $0.339 * *$ & $-0.399 * *$ & $-0.303 * *$ & 1 & & \\
\hline DO & -0.02 & -0.062 & $0.383 * *$ & 0.035 & $-0.435 * *$ & $-0.292 * *$ & -0.079 & -0.105 & -0.157 & $0.443 * *$ & 1 & \\
\hline $\mathrm{EC}$ & $0.295 * *$ & $0.336^{* *}$ & -0.147 & $0.552 * *$ & 0.064 & -0.026 & 0.047 & $0.633 * *$ & $0.679 * *$ & $-0.310 * *$ & $-0.239 *$ & 1 \\
\hline
\end{tabular}

\section{Notes:}

$2 *$ strong positive correlation coefficients at the 0.05 level (two-tailed).

$3 * *$ strong positive correlation coefficients at the 0.01 level (two-tailed). 


\section{Table 4 (on next page)}

Varimax rotated component matrix of dissolved heavy metals in the tributaries of Lake Aha. 


\begin{tabular}{ccccc}
\hline Variables & PC1 & PC2 & PC3 & Communalities \\
\hline $\mathrm{Mn}$ & 0.96 & -0.12 & 0.07 & 0.93 \\
$\mathrm{Co}$ & 0.95 & 0.06 & 0.05 & 0.92 \\
$\mathrm{Al}$ & 0.79 & -0.20 & 0.11 & 0.67 \\
$\mathrm{Ni}$ & 0.74 & -0.05 & 0.43 & 0.72 \\
$\mathrm{Ba}$ & -0.08 & 0.88 & 0.16 & 0.75 \\
$\mathrm{~V}$ & -0.11 & 0.84 & 0.06 & 0.79 \\
$\mathrm{Sb}$ & -0.03 & 0.64 & -0.10 & 0.73 \\
$\mathrm{Sr}$ & 0.02 & 0.25 & 0.85 & 0.42 \\
$\mathrm{Fe}$ & 0.33 & -0.18 & 0.78 & 0.80 \\
\hline Eigenvalues (\%) & 3.11 & 2.03 & 1.58 & \\
Variance (\%) & 34.58 & 22.61 & 17.55 & \\
Cumulative (\%) & 34.58 & 57.19 & 74.74 &
\end{tabular}

\section{Notes:}

2 Extraction method: Principal component analysis.

3 Rotation method: Varimax with Kaiser normalization. 


\section{Table 5 (on next page)}

Hazard quotient and hazard index for each heavy metal in the tributaries of Lake Aha. 


\begin{tabular}{|c|c|c|c|c|c|c|}
\hline $\mathrm{PC}$ & Eigenvalues & $\begin{array}{c}\text { Relative } \\
\text { Eigenvalue }\end{array}$ & Variable & $\begin{array}{c}\text { Loading } \\
\text { Value }\end{array}$ & $\begin{array}{l}\text { Relative Loading } \\
\text { Value on Same PC }\end{array}$ & Weight \\
\hline \multirow{6}{*}{1} & \multirow{6}{*}{3.11} & \multirow{6}{*}{0.46} & $\mathrm{Mn}$ & 0.96 & 0.25 & 0.12 \\
\hline & & & Co & 0.95 & 0.25 & 0.12 \\
\hline & & & $\mathrm{Al}$ & 0.79 & 0.21 & 0.10 \\
\hline & & & $\mathrm{Ni}$ & 0.74 & 0.20 & 0.09 \\
\hline & & & $\mathrm{Fe}$ & 0.33 & 0.09 & 0.04 \\
\hline & & & Total & 3.76 & 1 & 0.46 \\
\hline \multirow{4}{*}{2} & \multirow{4}{*}{2.03} & \multirow{4}{*}{0.30} & $\mathrm{Ba}$ & 0.88 & 0.37 & 0.11 \\
\hline & & & $\mathrm{V}$ & 0.84 & 0.36 & 0.11 \\
\hline & & & $\mathrm{Sb}$ & 0.64 & 0.27 & 0.08 \\
\hline & & & Total & 2.36 & 1 & 0.30 \\
\hline \multirow{4}{*}{3} & \multirow{4}{*}{1.58} & \multirow{4}{*}{0.24} & $\mathrm{Sr}$ & 0.89 & 0.42 & 0.10 \\
\hline & & & $\mathrm{Fe}$ & 0.82 & 0.38 & 0.09 \\
\hline & & & $\mathrm{Ni}$ & 0.43 & 0.20 & 0.05 \\
\hline & & & Total & 2.14 & 1 & 0.23 \\
\hline Total & 6.73 & & & & & 1 \\
\hline
\end{tabular}

1 Notes:

2 Weight was calculated by relative eigenvalue times relative loading value. 


\section{Table 6(on next page)}

Hazard quotient (HQ) and reference dose (RfD) for dissolved heavy metals in three tributaries of Lake Aha. 


\begin{tabular}{|c|c|c|c|c|c|c|c|c|c|}
\hline & \multicolumn{2}{|c|}{$H Q_{\text {ingestion }}$} & \multicolumn{2}{|c|}{$H Q_{\text {dermal }}$} & \multicolumn{2}{|c|}{ HI } & \multirow{2}{*}{$\mathbf{K}_{\mathbf{p}}{ }^{\mathbf{a}}$} & \multirow{2}{*}{$\mathbf{R f D}_{\text {ingestion }} \mathbf{b , c}$} & \multirow{2}{*}{$\mathbf{R f D}_{\text {dermal }} \mathbf{b , c}$} \\
\hline & Adults & Children & Adults & Children & Adults & Children & & & \\
\hline Mn & $4.27 \times 10^{-4}$ & $6.37 \times 10^{-4}$ & $5.57 \times 10^{-5}$ & $1.64 \times 10^{-4}$ & $4.82 \times 10^{-4}$ & $8.01 \times 10^{-4}$ & $1.00 \times 10^{-3}$ & 24 & 0.96 \\
\hline Co & $5.66 \times 10^{-3}$ & $8.45 \times 10^{-3}$ & $5.90 \times 10^{-5}$ & $1.74 \times 10^{-4}$ & $5.71 \times 10^{-3}$ & $8.62 \times 10^{-3}$ & $4.00 \times 10^{-4}$ & 0.3 & 0.06 \\
\hline Al & $1.35 \times 10^{-4}$ & $2.02 \times 10^{-4}$ & $3.53 \times 10^{-6}$ & $1.04 \times 10^{-5}$ & $1.39 \times 10^{-4}$ & $2.13 \times 10^{-4}$ & $1.00 \times 10^{-3}$ & 1000 & 200 \\
\hline $\mathbf{N i}$ & $1.67 \times 10^{-3}$ & $2.50 \times 10^{-3}$ & $4.36 \times 10^{-5}$ & $1.29 \times 10^{-4}$ & $1.71 \times 10^{-3}$ & $2.62 \times 10^{-3}$ & $2.00 \times 10^{-4}$ & 20 & 0.8 \\
\hline Ba & $3.47 \times 10^{-3}$ & $5.18 \times 10^{-3}$ & $2.59 \times 10^{-4}$ & $7.63 \times 10^{-4}$ & $3.73 \times 10^{-3}$ & $5.95 \times 10^{-3}$ & $1.00 \times 10^{-3}$ & 200 & 14 \\
\hline $\mathbf{V}$ & $9.05 \times 10^{-3}$ & $1.35 \times 10^{-2}$ & $4.73 \times 10^{-3}$ & $1.39 \times 10^{-2}$ & $1.38 \times 10^{-2}$ & $2.75 \times 10^{-2}$ & $1.00 \times 10^{-3}$ & 1 & 0.01 \\
\hline Sb & $6.82 \times 10^{-2}$ & $1.02 \times 10^{-1}$ & $1.78 \times 10^{-2}$ & $5.25 \times 10^{-2}$ & $8.60 \times 10^{-2}$ & $1.54 \times 10^{-1}$ & $1.00 \times 10^{-3}$ & 0.4 & 0.008 \\
\hline $\mathrm{Fe}$ & $1.37 \times 10^{-3}$ & $2.05 \times 10^{-3}$ & $3.58 \times 10^{-5}$ & $1.06 \times 10^{-4}$ & $1.41 \times 10^{-3}$ & $2.16 \times 10^{-3}$ & $1.00 \times 10^{-3}$ & 700 & 140 \\
\hline $\mathrm{Sr}$ & $1.89 \times 10^{-2}$ & $2.82 \times 10^{-2}$ & $4.93 \times 10^{-4}$ & $1.45 \times 10^{-3}$ & $1.94 \times 10^{-2}$ & $2.97 \times 10^{-2}$ & $1.00 \times 10^{-3}$ & 600 & 120 \\
\hline
\end{tabular}

\section{Notes:}

2 a US (EPA 2004).

3 b Wang et al (2017).

$4 \quad$ c Wu et al (2009).

5 